\title{
An atypical pleural effusion
}

\author{
A Smyth, L Redahan, T Rahman, C Wall, G J Mellotte \\ Department of Nephrology, Adelaide and Meath Hospital, Dublin, Ireland
}

Correspondence to A Smyth, andrewsmyth@physicians.ie

\section{DESCRIPTION}

A 51-year-old male presented with increasing dyspnoea, pleuritic chest pain and pain in the right shoulder tip. Clinical examination revealed stony dull percussion and absent breath sounds on the right mid and lower zones of the chest. He had no clinical evidence of heart failure or systemic volume overload, the main differential diagnoses in this case. His background history was significant for end stage renal disease due to focal segmental glomerulosclerosis with failed renal allograft. A Tenchkoff catheter had recently been sited and he had commenced peritoneal dialysis. Chest radiograph showed evidence of a large right pleural effusion (figure 1). A peritoneal dialysis drainage bag was immediately attached which drained 1.5 litres with immediate symptomatic relief, followed by further intermittent drainages. Peritoneal dialysis was immediately discontinued and the patient was transitioned to haemodialysis. Follow-up chest radiograph showed resolution of the pleural effusion (figure 2). There was no evidence of a localised pleural process.

Dialysate leakage occurs in approximately $5 \%$ of chronic ambulatory peritoneal dialysis (CAPD) patients, is more commonly right sided and occurs due to the presence of a diaphragmatic hernia. Pleural aspiration will reveal a high glucose content in the fluid, due to the presence of dialysate. Peritoneal scintigraphy can be used for diagnosis. ${ }^{1}$ Treatment options include pleural sclerotherapy (talc or tetracycline) or discontinuation of CAPD. A minority of patients

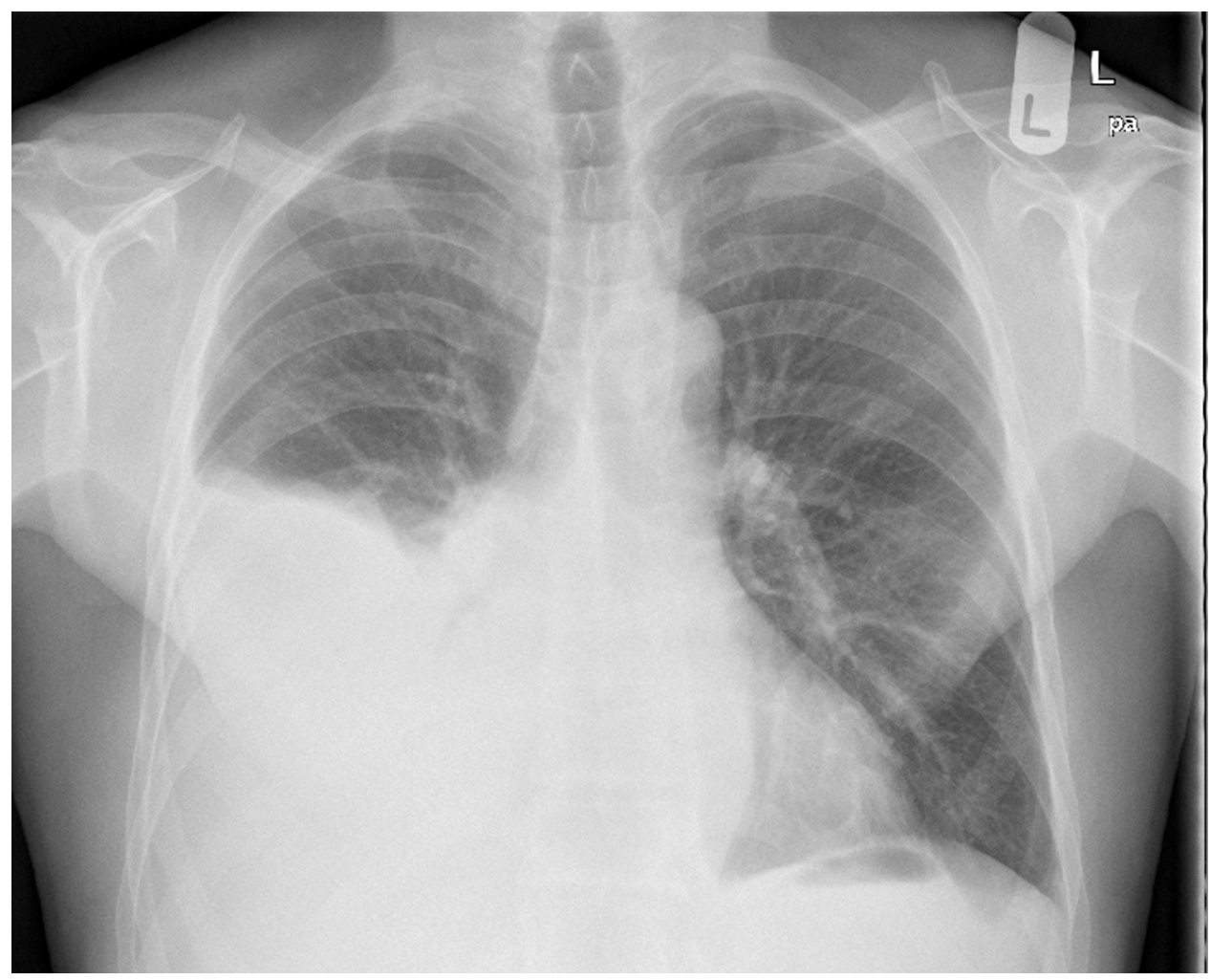

Figure 1 Plain chest radiograph showing large right sided pleural effusion with loss of cardiophrenic angle, and loss of lung fields over the right mid and lower zones. 


\section{BMJ Case Reports}

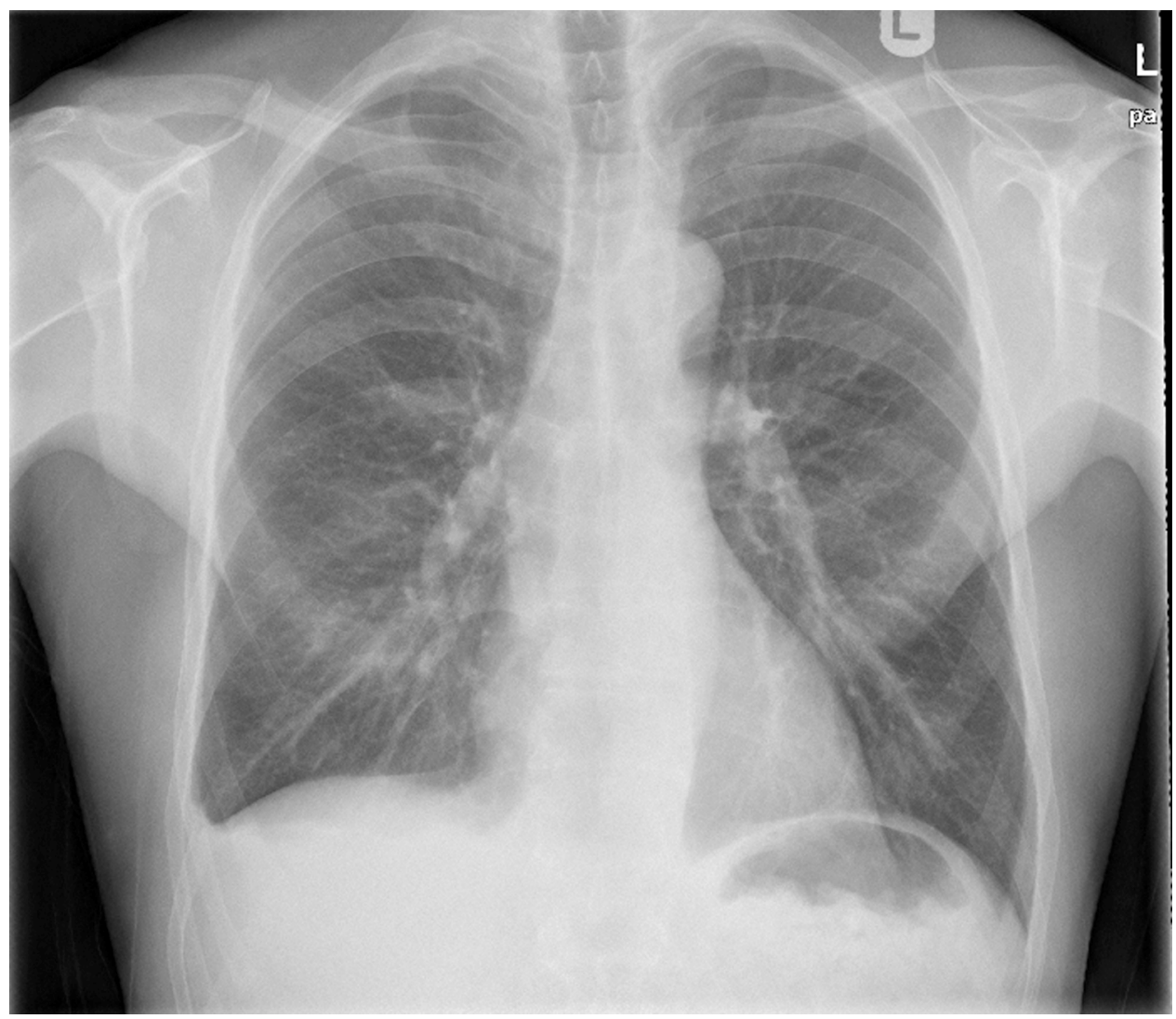

Figure 2 Plain chest radiograph showing near complete resolution of large right sided pleural effusion.

may require thoracotomy. ${ }^{2}$ This is an uncommon cause of a pleural effusion and we suggest vigilance in the peritoneal dialysis population.

\section{Competing interests None.}

Patient consent Obtained.

\section{REFERENCES}

1. Tokmak H, Mudun A, Türkmen C, et al. The role of peritoneal scintigraphy in the detection of continuous ambulatory peritoneal dialysis complications. Ren Fail 2006;28:709-13.

2. Szeto CC, Chow KM. Pathogenesis and management of hydrothorax complicating peritoneal dialysis. Curr Opin Pulm Med 2004;10:315-19.

\footnotetext{
This pdf has been created automatically from the final edited text and images.

Copyright 2010 BMJ Publishing Group. All rights reserved. For permission to reuse any of this content visit http://group.bmj.com/group/rights-licensing/permissions.

BMJ Case Report Fellows may re-use this article for personal use and teaching without any further permission.

Please cite this article as follows (you will need to access the article online to obtain the date of publication).

Smyth A, Redahan L, Rahman T, Wall C, Mellotte GJ. An atypical pleural effusion. BMJ Case Reports 2010;10.1136/bcr.12.2009.2573, date of publication

Become a Fellow of BMJ Case Reports today and you can:

- Submit as many cases as you like

- Enjoy fast sympathetic peer review and rapid publication of accepted articles

- Access all the published articles

- Re-use any of the published material for personal use and teaching without further permission

For information on Institutional Fellowships contact consortiasales@bmjgroup.com

Visit casereports.bmj.com for more articles like this and to become a Fellow
} 